\title{
Erratum to: Estimation of Some Oxidative Stress Parameters and Blood Pressure After Administration of Endothelin-1 (ET-1) in Rats
}

Paulina Kleniewska • Agata Kowalczyk •

Wlodzimierz Ciesla $\cdot$ Anna Goraca

Published online: 13 December 2014

(c) Springer Science+Business Media New York 2014

\section{Erratum to: Cell Biochem Biophys}

DOI 10.1007/s12013-014-0371-0

Unfortunately, the given and family names of all the authors were swapped in the earlier publication of the article. The names have been corrected in the original publication and they are corrected with this erratum as well.

The online version of the original article can be found under doi:10.1007/s12013-014-0371-0.

P. Kleniewska $(\square) \cdot$ A. Kowalczyk · W. Ciesla · A. Goraca Experimental and Clinical Physiology, Department of Cardiovascular Physiology, Medical University of Lodz, ul. Mazowiecka 6/8, 92-215 Lodz, Poland e-mail: kleniewska.p@interia.pl 